\title{
MANAGING MIGRATION: TURKISH PERSPECTIVE
}

İhsan GÜLAY ${ }^{1}$
Received Date (Başvuru Tarihi): 05/04/2018

Accepted Date (Kabul Tarihi): 23/04/2018

Published Date (Yayın Tarihi): 20/04/2018

\begin{abstract}
Conducting migration studies is of vital importance to Turkey, a country which has been experiencing migration throughout history due to its "open doors policy". The objective of this study is to evaluate the strategic management of migration in Turkey in order to deal with the issue of migration. The main focus of the study is Syrian migrants who sought refuge in Turkey due to the civil war that broke out in their country in April 2011. This study demonstrates the policies and processes followed by Turkey for Syrian migration flow in terms of the social acceptance and harmonisation of the migrants within a democratic environment. The study addresses some statistical facts and issues related to Syrian migration as it has become an integral part of daily life in Turkey. The study also reviews how human rights are protected in the migration process. The study will provide insights for developing sound strategic management policies for the migration issue.
\end{abstract}

Keywords: Migration, Syrian migrants, Strategic Management

JEL Codes: M10, M14, N40

\section{GÖÇÜ YÖNETMEK: TÜRKIYE PERSPEKTIFİ}

\section{ÖZ}

Göç meselesini irdelemek özellikle "açık kapı politikası" izleyerek tarih boyunca göçlere sahne olmuş Türkiye gibi bir ülke için son derece önem teşkil etmektedir. Bu çalışmanın amacı göç meselesinin üstesinden gelebilmek için Türkiye'nin stratejik yönetim şeklini değerlendirmektir. 2011 yılının Nisan ayında ülkelerinde patlak veren iç savaş̧tan kaçarak Türkiye'ye sığınan Suriyeli gö̧̧menler çalışmanın odak noktasını oluşturmaktadır. Çalışma, Suriyeli göçmen akımında göçmenlerin demokratik ortamda toplumsal kabul ve uyum konusunda Türkiye'nin izlediği politika ve süreçleri ele almaktadır. Çalışmanın kapsamında Türkiye'de günlük yaşamın bir parçası olan Suriyeli gö̧̧men ile ilintili bir takım istatistiki tespitler yer almaktadır. Göç sürecinde insan haklarının ne şekilde korunduğu da çalışmanın ele aldı̆̆ı konulardan biridir. Çalışmada, gö̧̧ meselesinde sağglılı stratejik yönetim politikaları geliş̧tirilmesi adına öngörülerde bulunmaya çalışılmış̧ır.

Anahtar Kelimeler: Göç, Suriyeli göçmenler, Stratejik Yönetim

JEL Kodları: M10, M14, N40

${ }^{1}$ Dr.,, Maltepe University, ihsangulay@maltepe.edu.tr

http://orcid.org/0000-0003-3507-9241 


\section{INTRODUCTION}

Migration, defined as "moving from one place to another" in the dictionary, is "(to some extent) the permanent movement of people in large groups across boundaries into new settlement areas due to various reasons" with its sociological meaning.

As we all know, Turkey has traditionally been known as a country of emigration. After the Second World War (1960-1975); for instance, labour migration was experienced especially to Germany. There are nearly 3 million gastarbeiters all around Europe as a result of workers' settlement. Turkey, by the way, is a country of immigration as well. The difference between "emigration and immigration" lies in the point of view focusing on the direction of the movement. When the focus is on departure, the word "emigration" is used. If the point of view is on arrival “immigration" is preferred (vocabulary.com). Turkey's transformation from emigration to immigration is a result of its rich Anatolian culture and history, which empowers societal relations. What should be considered here is that, migrants' preference for Turkey could also be due to its economic growth as well as its strategic geographical location. Turkey, as a bridge between Asia, Europe and Middle East, is a natural regional attraction for migrants. These characteristics combined with Turkish hospitality have made Turkey an eligible country for migration throughout history. During the Ottoman Empire, those coming to Turkey were welcomed regardless of their religion and race. The main examples for the mass and individual asylum movements in the mentioned era are depicted in Table 1.

Table 1: Migration in Ottoman Empire Period

\begin{tabular}{|l|l|l|l|}
\hline When & Who & From & Reason \\
\hline 1492 & Thousands of Jewish people & Spain & Racial extermination \\
\hline 1672 & $\begin{array}{l}\text { İbrahim Müteferrika, pioneer in printing } \\
\text { Cont Ödön Seçenyi (Seçenyi Paşa), pioneer in fire } \\
\text { fighting }\end{array}$ & Hungary & Thököly Rebellion \\
\hline 1699 & King of Hungary Thököly Imre and his wife & Hungary & Thököly Rebellion \\
\hline 1709 & $\begin{array}{l}\text { King of Sweden Charles together with almost 2 thousand } \\
\text { people }\end{array}$ & Sweeden & \\
\hline 1718 & King of Hungary II. Rakoczy Ferenc & Hungary & Passarowitz Treaty \\
\hline $1783-1922$ & Crimean Tatars and Noghais & Crimean & Russian annexation \\
\hline 1841 & $\begin{array}{l}\text { Prince Adam Czartorski, one of the leaders of Poland } \\
\text { Revolution }\end{array}$ & Poland & Poland Revolution \\
\hline 1849 & Prince Lajos Kossuth and almost 3 thousand people & Hungary & $\begin{array}{l}\text { loosing 1848 Hungary Freedom } \\
\text { war }\end{array}$ \\
\hline $1856-1864$ & 1.500.000 Caucasian people & Caucasia & escaping from Russian Army \\
\hline 1917 & Vrangel and almost 135 thousand people & Russia & Bolshevik Revolution \\
\hline
\end{tabular}

Source: Republic of Turkey, Ministry of Interior Directorate General of Migration Management http://www.goc.gov.tr/icerik6/history-ofmigration 915 915 1026 icerik, accessed on March 1, 2018.

Mass migration flows to Turkey continued in the early Republican Period and onward. The most concrete examples for these movements are summarised in Table 2 with the years, number of migrants and the reasons behind the migrations from the Balkans, Germany, Iraq, Bulgaria Bosnia, Kosovo, Macedonia and Syria. 
Table 2: Journey from Emigration to Immigration

\begin{tabular}{|c|c|c|c|}
\hline Year(s) & From & No. of migrants & Reason \\
\hline $1922-1938$ & Greece & 384.000 & Population exchange \\
\hline 1923-1945 & Balkans & 800.000 & Mass migration \\
\hline 1933-1945 & Germany & 800 & Upon agreements \\
\hline 1988 & Iraq & 51.542 & Iraq War \\
\hline 1989 & Bulgaria & 345.000 & War \\
\hline 1991 & Iraq & 467.489 & Gulf War \\
\hline 1992-1998 & Bosnia & 20.000 & War \\
\hline 1999 & Kosovo & 17.746 & Aftermath of the incidents \\
\hline 2001 & Macedonia & 10.500 & War \\
\hline April 2011- Oct 2017 & Syria & 3.500 .000 & Domestic turmoil \\
\hline April 2011- Oct 2017 & transit & Over 1.500 .000 & Via ways off the record \\
\hline
\end{tabular}

Source: Republic of Turkey, Ministry of Interior Directorate General of Migration Management http://www.goc.gov.tr/icerik6/history-ofmigration_915_915_1026_icerik accessed on March 1, 2018.

\section{THE QUESTION OF MIGRATION IN TURKEY}

No migrant group trying to find asylum has been refused throughout Turkish history; in the Eras of the Seljuk Empire, the Ottoman Empire and the Turkish Republic with a few exceptions due to warfare. Well-known for its hospitality, Turkey has always embraced those in need. This approach has led Turkey to become the country with the highest population of migrants and asylum seekers in the world. According to UNHRS statistics, Turkey hosts 4 million forcibly displaced people out of 65.6 million in total. The number of irregular migrants on a yearly basis is illustrated in Fig 1 and supplemented with Fig. 2, which shows the top ten countries with residence permit in Turkey.

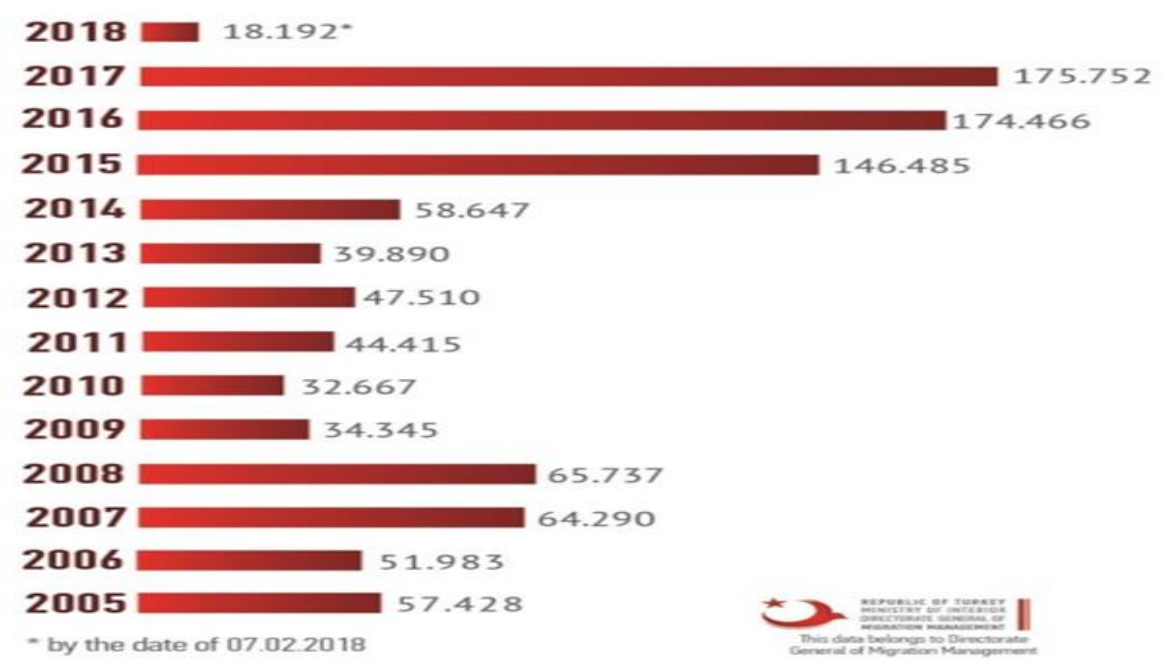

Figure 1: The Number of Irregular Migrants

Source: Republic of Turkey, Ministry of Interior Directorate General of Migration Management http://www.goc.gov.tr/icerik6/residence-permits $915 \quad 1024 \quad 4745$ icerik accessed on March 1, 2018. 


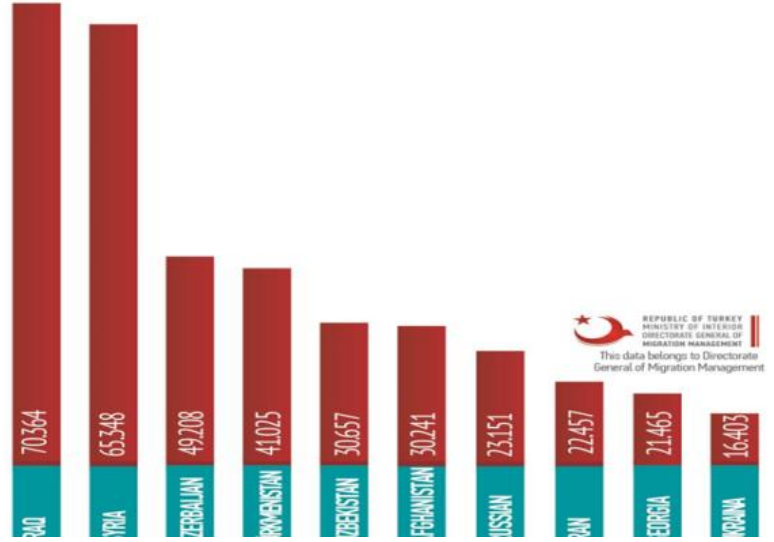

Figure 2: Top Ten Countries with Residence Permit in Turkey (2017)

Source: Republic of Turkey, Ministry of Interior Directorate General of Migration Management http://www.goc.gov.tr/icerik6/residence-permits_915_1024_4745_icerik accessed on March 1, 2018.

Within the limits of its economic power, Turkey strives towards creating an accommodating environment for migrants. The figures in Tables 3, 4 and 5 clearly demonstrate the wide range of opportunities provided for migrants from temporary migrant shelter centres to educational opportunities and healthcare services.

Table 3: Temporary Migrant Shelters

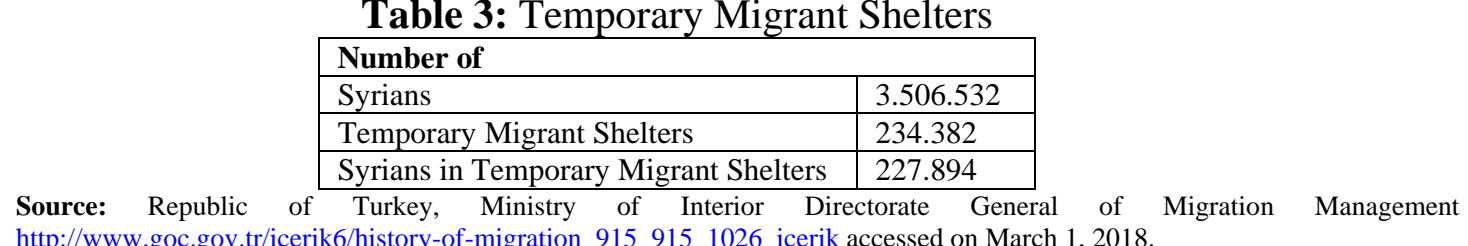

Table 4: Education Provided for Migrants

\begin{tabular}{|c|c|c|c|c|c|c|c|c|c|c|}
\hline \multicolumn{5}{|c|}{ Number of Students } & \multicolumn{4}{|l|}{ Levels } & \multicolumn{2}{|c|}{ Adult Education } \\
\hline $\begin{array}{l}\text { Temporar } \\
\text { y } \\
\text { Migrant } \\
\text { Centres }\end{array}$ & $\begin{array}{l}\text { State } \\
\text { School } \\
\text { s }\end{array}$ & $\begin{array}{l}\text { Temporar } \\
\text { y } \\
\text { Education } \\
\text { Centres }\end{array}$ & $\begin{array}{l}\text { Open } \\
\text { School } \\
\mathrm{s}\end{array}$ & $\begin{array}{l}\text { TOTA } \\
\text { L }\end{array}$ & $\begin{array}{l}\text { Pre- } \\
\text { schoo } \\
1\end{array}$ & $\begin{array}{l}\text { Primar } \\
\text { y } \\
\text { School }\end{array}$ & $\begin{array}{l}\text { Secondar } \\
\text { y } \\
\text { School }\end{array}$ & $\begin{array}{l}\text { High } \\
\text { Schoo } \\
1 \\
\text { and } \\
\text { others }\end{array}$ & $\begin{array}{l}\text { Vocation } \\
\text { al } \\
\text { Educatio } \\
\mathrm{n}\end{array}$ & $\begin{array}{l}\text { General } \\
\text { Educatio } \\
\mathrm{n}\end{array}$ \\
\hline 83.246 & $\begin{array}{l}350.49 \\
3\end{array}$ & 170.267 & 8.597 & $\begin{array}{l}612.60 \\
3\end{array}$ & $\begin{array}{l}33.33 \\
7\end{array}$ & $\begin{array}{l}378.24 \\
4\end{array}$ & 141.218 & $\begin{array}{l}59.80 \\
4\end{array}$ & 87.168 & 216.060 \\
\hline
\end{tabular}

Source: Republic of Turkey, Ministry of Interior Directorate General of Migration Management http://www.goc.gov.tr/icerik6/history-ofmigration 9159151026 icerik accessed on March 1, 2018.

Table 5: Healthcare Provided for Migrants

\begin{tabular}{|l|l|l|l|l|l|l|}
\hline \multicolumn{2}{|l|}{ Temporary Migrant Centres } & \multicolumn{4}{l|}{ Healthcare Services in Turkey } & Operation \\
\hline Doctor & $\begin{array}{l}\text { Healthcare } \\
\text { Personnel }\end{array}$ & Polyclinic & Out-patient & In-patient & Delivery & \\
\hline 83.246 & 350.493 & 33.337 & 378.244 & 141.218 & 59.804 & 87.168 \\
\hline
\end{tabular}

Source: Republic of Turkey, Ministry of Interior Directorate General of Migration Management http://www.goc.gov.tr/icerik6/history-ofmigration $915 \quad 915 \quad 1026$ icerik accessed on March 1, 2018.

The ways in which Turkey deals with this migration phenomenon have been made evident through the ranking of and awards bestowed on the country. In 2014 Turkey ranked 4th in the list of migrant hosting countries. The AFKEN Project, operating and observing all 
the administrative work in temporary sheltering centres, won «the UN Public Services Award» in 2015. Additionally, Turkey became «the most generous donor» of the world in 2016 by sparing $0,75 \%$ of its national income to migration. It ranks second in the world after America for humanitarian aid, and was awarded the «most generous donor» title due to its allocation for migrants according to 2017 Global Humanitarian Assistance Report (Disaster and Emergency Management Presidency (AFAD); UNHRC).

It is not easy for governments to handle the migration process without support. Migration should also be of concern to many stakeholders in order to achieve the economic and social integration of migrants. The stakeholders of migration policies in Turkey are listed in Table 6.

Table 6: Stakeholders of Migration Policies

\begin{tabular}{|l|l|}
\hline Directorate General of Migration Management & Gendarmerie General Command \\
Disaster and Emergency Management Presidency (AFAD) & Turkish Land Forces \\
Ministry of Foreign Affairs & Coast Guard Command \\
Ministry of Development & General Directorate of Security \\
Ministry of Labour and Social Security & Local and District Governorships \\
Ministry of Family and Social Policies & $\begin{array}{l}\text { Municipalities } \\
\text { NGO's, educational institutions, hospitals, etc. }\end{array}$ \\
Source: Republic of Turkey, Ministry of Interior Directorate General of Migration Management \\
http://www.goc.gov.tr/icerik6/laws 913 980 981 icerik accessed on March 1, 2018.
\end{tabular}

There are many administration and regulation policies on migration in Turkey as depicted in Table 7. The legislative regulations are:

- Migrants Law 6458 on Foreigners and International Protection (published in the Official Gazette No. 28615 dated 11.04.2013). "The purpose of this law is to regulate the principles and procedures with regard to foreigners' entry into, stay in and exit from Turkey, and the scope and implementation of the protection to be provided for foreigners who seek protection from Turkey, and the establishment, duties, mandate and responsibilities of the Directorate General of Migration Management under the Ministry of Interior." (Ministry of Interior, Directorate General of Migration Management, http://www.goc.gov.tr/files/files/eng_minikanun_5_son.pdf)

- Turquoise Card: "The document that grants the foreigner right of work permanently in Turkey, and the right of residence to his/her spouse and children who are dependent in line with governing legislation." International Workforce Law No. 6735. This card is similar to the American "Green Card" in the sense that it is given to foreigners with the capacity to make contributions to the Turkish economy, science, technology, employment etc. (Turkish Laborlaw, 2018). 
Table 7: Administration of Migration Policies

\begin{tabular}{|r|l|}
\hline National Legislation & International Legislation \\
\hline Laws & Universal Declaration of Human Rights \\
$-\quad$ Passport Law & European Convention on Human Rights \\
$-\quad$ Settlement Law & International Convention on the Protection of the \\
$-\quad$ Law on Work Permit for Foreigners & Families \\
$-\quad$ Duties Law & European Convention on Legal Status of Migrant \\
$-\quad$ Foreign Direct Investment Law & Workers \\
$-\quad$ Turkish Citizenship Law & The 1951 Geneva Convention and 1967 Protocol on \\
Regulations & the Status of Migrants \\
Instructions & Council of Europe Convention on Action Against \\
Circulars & Human Trafficking \\
Manifestos & 2013 Foreign and International Protection Law \\
Cabinet Decrees & 2014 Temporary Protection Law \\
Information Systems of Legislation & \multicolumn{1}{|c|}{} \\
\hline Source: Republic of Turkey, Ministry of Interior
\end{tabular}

http://www.goc.gov.tr/icerik6/laws_913 980_981_icerik accessed on March 1, 2018.

\section{SYRIAN MIGRATION TO TURKEY}

Migration being a vast topic of debate both for Turkey and around the world, for the purposes of this article, Syrian migration will also be discussed in detail. Turkey, which has historically been known as a country of emigration has recently become a country of immigration as well. For the first time in its history, Turkey has witnessed an unprecedented inflow of migrants. After the still-raging civil war uprose in 2011, almost 5.1 million Syrians were forced to flee to neighbouring countries, Europe, Canada or the US. The number of internally displaced Syrians is now 6.5 million (MPI, 2018). This number will likely increase when unregistered migrants are taken into account. The number of Syrian migrants hosted in Turkey (Fig 3) could justify the motive behind the country becoming the focus of this issue.

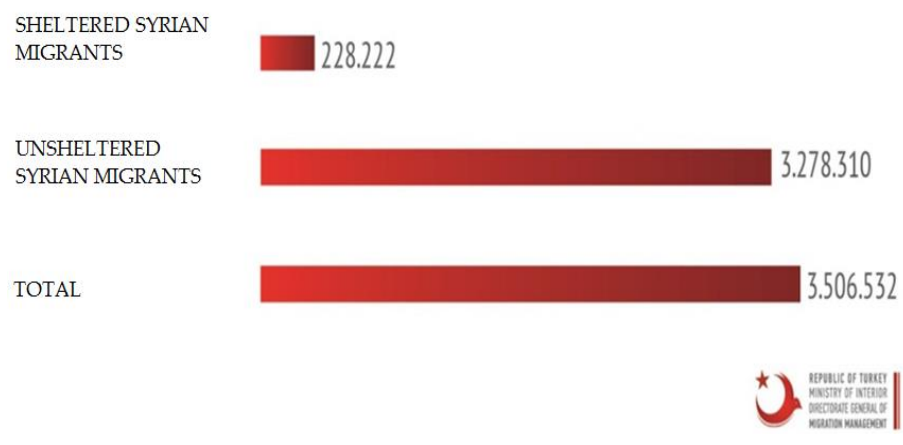

Figure 3: Migrants in and out of Temporary Shelter Centres

Source: Republic of Turkey, Ministry of Interior Directorate General of Migration Management http://www.goc.gov.tr/icerik6/historyof-migration_915 915_1026_icerik accessed on March 1, 2018. 


\subsection{Profiles of Syrian Migrants}

$44 \%$ of Syrian migrants in Turkey are children and $31 \%$ are women, who are in need of special protection. $12 \%$ of these are children aged four and under with TP (temporary protection) status as being stateless, granted neither Turkish nor Syrian citizenship (MPI, 2018). $75 \%$ of Syrian migrants in total are women and children, who are subjected to social upheaval and gender discrimination and abuse, and are forced to live in conditions that no human being should have to endure in the countries they have fled from.

\subsection{Economic Side of Syrian Migration}

The presence of refugees compounds the already prevailing economic, environmental, social and, at times, political difficulties in Turkey. Syrian migration wave amounts to $1 \%$ GDP of Turkey. The high budget spent on Syrian migrants is demonstrated in Table 8 .

Table 8: High Budget Spent on Syrian Migrants

Table 8: High Budget Spent on Syrian Migrants
\begin{tabular}{|l|l|l|}
\hline Year & Amount (billion \$ ) & Budget item \\
\hline 2017 & $3,08 /$ year - 22 (in total) & education \\
\hline 2017 & $1,84 /$ year-6,1 (in total) & security \\
\hline 2017 & $3,26 /$ year & healthcare \\
\hline $2011-2018$ & 34 & cumulative \\
\hline
\end{tabular}

Source: Huffpost, https://www.huffingtonpost.com/entry/turkey-syrian-refugees us 55fbd728e4b08820d91830 73 (March 19, 2018)

It is worth pointing out here that Turkey benefits from Syrian migrants' contribution to trade. The impact of Syrian migrants on Turkey is complex and multifaceted. With the Syrian influx, there is a great demand for goods and services for their care. As a result, the labour market has been affected greatly. Syrian migrants are also economic actors in Turkey with their contribution not only to labour supply but also to trade, which implies that migration could turn out to be positive in the long run. The share of Syrian companies in total foreign partnerships reached 26\% in 2015. The number of Syrian companies was 157 in 2012 whereas it was 1599 in 2015. However, it should be stated that in order to become more powerful and stable to meet the increasing demands, the Turkish economy needs some supplementation (Esen \& Binatl, 2017).

Turkey bends over backwards both financially and spiritually in the hopes of collaboration with the EU. Although the EU countries have made commitments to help with the Syrian migration issue, they have not fully contributed yet. 


\section{LIVING TOGETHER IN DEMOCRACY}

Having a young population easily adaptable to change makes Turkish society highly tolerant towards migrants.

Despite many hot debates, Syrian migrants' contribution to many areas such as culture, art, education, trade, etc. has helped create positive public opinion. Integration into society is improving with the help of mutual tolerance, indulgence, collaboration and solidarity.

Although migration poses some risks, with comprehensive strategies, all risks can turn into opportunities (Gündüz, 2018) for both nationalities.

Migration is not leaving a country; it is leaving one pain for another one. According to a study carried out by Hacettepe University, Turkish people's perceive Syrian migrants as people who escape from persecution (41,1\%) and as guests in Turkey (20,8\%) (Erdoğan, 2014), which reflects how Turkey has embraced them.

What Syrian migrants are offered in a democratic environment embellished with sentiment is humanitarian treatment, temporary protection (TP), right to travel, education and healthcare opportunities, business life and residence permits.

\section{SUGGESTED GLOBAL MIGRANT POLICIES}

Turkey, having almost become an expert in carrying out a successful migration process, could become an example to the world. The policies it follows could be considered global. Turkey has been implementing a long term management and planning strategy including:

- $\quad$ social responsibility

- $\quad$ sharing the humanitarian plight

- global financial collaborations

- flexible migrant acceptance requirements

- complying with Human Rights

- collaboration between UNHCR and NGOs

- greater humanitarian assistance in besieged areas

- engagement of local authorities

- extra assistance for the vulnerable ones (disabled or elderly)

- technical help to Syrian entrepreneurs 
- practical actions towards providing migrants better settlement and integration opportunities

(https://www.crisisgroup.org/europe-central-asia/westerneuropemediterranean/turkey/248-turkeys-syrian-refugees-defusingmetropolitan-tensions; MPI, 2018; IAI, 2018).

\section{DISCUSSION}

Turkey has set an example with its migration policies to the world as it has been more sensitive to human rights than the pioneer countries on this issue. The concepts of global peace and harmony should be internalised in order to end polarisation. The humanitarian plight Syrian migrants go through forces all neighbouring European countries into a position of responsibility. The economic and social cost of all migration waves in Turkey should be supported by global collaboration, which will relieve the Turkish economy. Migrant acceptance requirements should be more flexible. The importance given to Human Rights should be reflected on Syrian migrants in order to increase the reliability. We should bear in mind that greater humanitarian assistance in besieged areas, deeper thought on the viability of safe zones, and more extensive resettlement of refugees are needed. UNHCR and NGOs should work hand in hand. It is not clear from time to time whether they are competitors or companions in migrant protection. Many NGOs are under-financed and they could be a threat to local safety.

It could be said that the expectations of Syrian migrants, the concerns and worries of host communities are all universal. However, what makes Turkey distinctive is the strategic management style it follows supported with high acceptance of Syrian migrants by Turkish society and the satisfaction of Syrians to Turkish hospitality. These two elements must be sustainable so that the Syrian migration wave does not turn into xenophobia. Social harmonisation policies should be carried out in this process (Tunç, 2015). The mitigation of the potential socioeconomic impact of migration on host countries, maximisation of social and economic benefits of migration and the support of Syrian Temporary Protection to be selfreliant are the steps to be taken. These actions are additional to the existing ones in order to create an attractive economic environment for work and residency. 


\section{REFERENCES}

Dil, A.N. (2014). Geçiçi Koruma Yönetmeliği Kabul Edildi [Temporary Protection Law was Approved]. Ankara Institute of Strategy.

Erdoğan, M.M.,(2014). Türkiye'deki Suriyeliler: Toplumsal Kabul ve Uyum Araştırması [Syrians in Turkey]. Hacettepe University Migration and Politics Research Center, Ankara.

Esen, O. \& Binatl1, A. O. (2017). The Impact of Syrian Refugees on the Turkish Economy: Regional Labour Market Effects. Social Sciences, 1-12.

Gün, Z.\& Bayraktar, F. (2008). The Role of Migration on Adjustment of Adolescents in Turkey. Turkish Journal of Psychiatry, 19(2), 167-176.

Gündüz, Ş. (2018). Preventing Blue Ocean from Turning into red Ocean: A Case Study of Room Escape Game. Journal of Human Sciences, 15(1), 1-7.

Huffpost, $\quad$ https://www.huffingtonpost.com/entry/turkey-syrian-refugees_us 55fbd728e4b08820d9183073 (March 19, 2018)

Tunç, Ş.A. (2015). Mülteci Davranışı ve Toplumsal Etkileri: Türkiye’deki Suriyelilere İlişkin Bir Değerlendirme [Migrant Behaviour and Social Effects: An Evaluation of Syrian Migrants in Turkey], Turkish Journal of TESAM Academy 2 (2). $29-63$

Instituto Affari Internazionali, http://www.iai.it/en/pubblicazioni/syrian-refugees-turkey-insecure-livesenvironment-pseudo-integration (March 18, 2018)

International Crisis Group, https://www.crisisgroup.org/europe-central-asia/western-europe mediterranean /turkey/248-turkeys-syrian-refugees-defusing-metropolitan-tensions (March 3, 2018)

Migration Policy Institute, https://www.migrationpolicy.org/article/unhcr-and-ngos-competitors-or-companionsrefugee-protection (March 11, 2018)

Ministry of Interior, Directorate General of Migration Management, http://www.goc.gov.tr/files/files/eng minikanun 5 son.pdf (March 2, 2018)

MPI (Migration Policy Institute), https://www.migrationpolicy.org/article/thinking-outside-camp-syrianrefugees-istanbul (March 1, 2018)

Republic of Turkey, Ministry of Interior Directorate General of Migration Management http://www.goc.gov.tr/icerik6/history-of-migration_915 915_1026_icerik March 1, 2018.

Syria Regional Refugee Response, http://data.unhcr.org/syrianrefugees /country.php?id=224 (February 19, 2018)

The Sabah, https://www.sabah.com.tr/gundem/2017/03/14/turkuaz-kart-yonetmeligi-resmi-gazetede (February $16,2018)$

Turkish Laborlaw, https://turkishlaborlaw.com/news/business-in-turkey/417-turkey-s-turquoise-card (March 19, 2018)

vocabulary.com, https://www.vocabulary.com/ (March 16, 2018) 